\title{
THE EDITOR'S DEPARTMENT
}

\section{Fulfilling a promise}

In my first Editor's Department (in Language 78.1.1-2, 2002), I noted (with some pride) that The Ohio State University (OSU) had been involved in various ways in the early days of the Linguistic Society of America and of Language itself. At the time, I promised to explore resources here at OSU, such as the University Archives, to determine what information might be gleaned about OSU's role in that formative period for our society. The piece that follows-departing somewhat from my usual format for this column in being coauthored (with one of Language's editorial assistants) - presents some preliminary results of this exploration, examining the early leaders and members of the LSA from the perspective of the interconnections and likely interactions among them, their 'networking' as it were, not only the figures here at OSU but to some extent those elsewhere as well. It thus provides what might (perhaps generously) be termed a 'micro-social-history' of the people and places involved in this period.

Brian D. Joseph

Columbus, Ohio

September 10, 2004

\section{The Ohio State University and Columbus and the foundations of the Linguistic Society of America*}

\author{
BRIAN D. JOSEPH \\ The Ohio State University
}

\author{
Hope C. DAwson \\ The Ohio State University
}

We take as our starting point an observation from Leonard Bloomfield's retrospective on two decades of the Linguistic Society of America (LSA): 'Only those who, before the year 1925, worked in almost complete isolation can appreciate the change that came about with the existence of the Linguistic society' (Bloomfield 1946:2). Bloomfield was, of course, in a good position to offer such an assessment, as he was involved in the formulation and circulation of the call for the formation of the society. It was not just Bloomfield, in fact, but a number of scholars at a variety of institutions who were involved, including other scholars at his own, The Ohio State University. We attempt in what follows to give a sense of how that isolation was overcome in the years leading up to the founding of the LSA, with our focus being on contributions made by individuals in Columbus, Ohio and at The Ohio State University (OSU).

Focusing on OSU and thus Columbus is appropriate (though surely one could examine the emergence of the LSA from the perspective of other cities and other institutions, as our discussion below suggests) because two key people in the founding of the LSA-Leonard Bloomfield and George Melville Bolling-hailed from the Columbus area and were affiliated with OSU. Bloomfield was one of the signers of the call for the formation of a linguistic society (cf. Language 1.6-7, 1925), ${ }^{1}$ a member of the LSA organizing committee, and the author of 'Why a linguistic society?', the first item published in Language. His reply to the titular question is: 'The immediate answer is simple: of course, we seek the possibility of meeting and knowing each other' (Bloom-

\footnotetext{
* An earlier version of this piece was presented at the annual meeting of the North American Association for the History of the Language Sciences (NAAHoLS) on January 8, 2004, in Boston, MA. We would like to thank the audience there, but especially Mark Amsler, for useful comments on this work.

${ }^{1}$ See Falk 2002 for a corrective to Joseph 2002 regarding Bloomfield's role.
} 
field 1925:1). Bolling also was one of the signers of the call and a member of the organizing committee, as well as the first editor of Language, from 1925-1939.

Moreover, a significant number of other foundation members (FMs) of the LSA were from OSU and therefore from Columbus or its environs. The FMs (listed in Language 1.26-36, 1925) numbered 264 in all and were a demographically diverse group comprising men, women, nonacademics, academics in language departments, academics in nonlanguage departments, and so on.

To give an idea of how OSU's and Columbus's FM representation compares with that of other institutions and cities, we present here a breakdown of the FM membership by geography and by institution. On each parameter, OSU, Ohio, and Columbus rank near the top of the membership lists.

The breakdown of FMs by geography is presented in Table 1 . We note that while the FMs were diverse from a geographic standpoint, in that thirty-one states (and the District of Columbia) and four countries are represented among the 264 original FMs, Ohio itself was home to sixteen FMs, the third-most, after Pennsylvania (with fiftyfive) and New York (with fifty-three).

$\begin{array}{lr}\text { Pennsylvania } & 55 \\ \text { New York } & 53 \\ \text { Ohio } & \mathbf{1 6} \\ \text { California } & 15 \\ \text { Massachusetts } & 14 \\ \text { Illinois } & 13 \\ \text { Maryland } & 12 \\ \text { Connecticut } & 9 \\ \text { Missouri } & 6 \\ \text { Nebraska } & 6 \\ \text { Washington, DC } & 6 \\ \text { Michigan } & 5\end{array}$

$\begin{array}{ll}\text { New Jersey } & 5 \\ \text { Virginia } & 5 \\ \text { Indiana } & 4 \\ \text { Wisconsin } & 4 \\ \text { Maine } & 3 \\ \text { Texas } & 3 \\ \text { Alabama } & 2 \\ \text { Arizona } & 2 \\ \text { Delaware } & 2 \\ \text { Georgia } & 2 \\ \text { Iowa } & 2 \\ \text { Kansas } & 2\end{array}$

TABLE 1 . FMs by state/country.

$\begin{array}{ll}\text { Tennessee } & 2 \\ \text { Washington } & 2 \\ \text { Alaska } & 1 \\ \text { Colorado } & 1 \\ \text { Florida } & 1 \\ \text { Oklahoma } & 1 \\ \text { South Carolina } & 1 \\ \text { Utah } & 1 \\ & \\ \text { Canada } & 6 \\ \text { Japan } & 1 \\ \text { Mexico } & 1\end{array}$

Moreover, looking at the academic members by affiliation (Table 2), we observe that while the most widely represented academic institution (out of the eighty-three represented in all) is the University of Pennsylvania with twenty-nine members, there were nine FMs who were associated with OSU, ranking it third by number of representatives among the FMs.

Turning now to OSU in particular, the following constitute the Ohio State contingent of FMs, as given in the initial roster:
Claude Anibal (Spanish)
Leonard Bloomfield (German)
George Melville Bolling (Greek)
Wallace Elden (Latin)
Erwin A. Esper (Psychology)
E. F. Hacker (Romance Langs.)
Olin H. Moore (Romance Langs.)
S. B. Smith (Latin)
Albert P. Weiss (Psychology)

In addition, a tenth FM was from Columbus, someone not overtly affiliated with OSU: Miss Ruth M. Keller is listed in the FM roster only with her address: '538 S. Champion Av., Columbus, O.' and was thus possibly a nonacademic. ${ }^{2}$ In Julia Falk's excellent account of the women FMs (Falk 1994), very little is said about Miss Keller, as indeed, very little information about her seems to have been available. From various OSU

\footnotetext{
${ }^{2}$ Bloomfield gave his home address rather than his office (as did others), but his institutional affiliation was listed as well. No such additional information was included with Ruth M. Keller's listing.
} 
U. of Pennsylvania

Columbia U.

Ohio State U.

Johns Hopkins U.

U. of Missouri

U. of Nebraska

Harvard U.

Hunter C.

Yale U.

Stanford U.

U. of Chicago

U. of Illinois

U. of Wisconsin

C. of the City of NY

Hobart C.

Lehigh U.

Princeton U.

UC Berkeley

Albion C.

Amer. Mus. of Natural History

Catholic U. (DC)

Goucher C.

Grove City C.

Indiana $U$.

Smith C.

Trinity C. (CT)

U. of Arizona

U. of Cincinnati

\begin{aligned} 29 & U. of Iowa \\ 11 & U. of Maine \\ 9 & U. of Richmond \\ 8 & U. of So. California \\ 6 & U. of Texas \\ 6 & U. of Toronto \\ 5 & Washington \& Jefferson C. \\ 5 & Whitman C. (WA) \\ 5 & Agnes Scott C. (GA) \\ 4 & Amherst C. \\ 4 & Baylor U. \\ 4 & Biblical Sem. (NY) \\ 4 & Bryn Mawr C. \\ 3 & Bucknell U. \\ 3 & C. of Missions (IN) \\ 3 & C. of William \& Mary \\ 3 & Cornell U. \\ 3 & Dalhousie C. \\ 2 & Field Mus. of Natural History \\ 2 & Hamilton C. \\ 2 & Howard C. (AL) \\ 2 & Jewish Center (OH) \\ 2 & McCormick Theol. Sem. \\ 2 & Mus. of the Amer. Ind. \\ 2 & New York U. \\ 2 & Northwestern U. \\ 2 & Ohio U. \\ 2 & Oklahoma Baptist U. \\ \hline & Be 2. FMs by insthutional afflitis \end{aligned}

$\begin{array}{ll}\text { Peabody C. } & 1 \\ \text { Purdue U. } & 1 \\ \text { Randolph-Macon Women's C. } & 1 \\ \text { Santa Ana Jr. C. } & 1 \\ \text { Smithsonian Inst. } & 1 \\ \text { Swarthmore C. } & 1 \\ \text { Syracuse U. } & 1 \\ \text { Tokyo Imperial U. } & 1 \\ \text { Tufts C. } & 1 \\ \text { UCLA } & 1 \\ \text { U. of Delaware } & 1 \\ \text { U. of Denver } & 1 \\ \text { U. of Florida } & 1 \\ \text { U. of Georgia } & 1 \\ \text { U. of Kansas } & 1 \\ \text { U. of Michigan } & 1 \\ \text { U. of Pittsburgh } & 1 \\ \text { U. of South Carolina } & 1 \\ \text { U. of Utah } & 1 \\ \text { Upsala C. } & 1 \\ \text { Vanderbilt U. } & 1 \\ \text { Victoria C. } & 1 \\ \text { Victoria Mus. } & 1 \\ \text { Wesley Collegiate Inst. } & 1 \\ \text { Western Reserve U. } & 1 \\ \text { Williams C. } & 1 \\ \text { Worcester Polytechnic Inst. } & 1\end{array}$

TABLE 2. FMs by institutional affiliation.

sources, however, we have determined who this Ms. Keller is likely to have been and thus offer this information as a complement to Falk's fine detective work.

From the OSU Office of Alumni Records, we have learned that there was a Ruth M. Keller at OSU in the mid-1910s. According to this information, a Ruth Mildred Keller received a B.A. in arts in 1914, a B.S. in education in 1915, and an M.A. in Latin in 1916. We feel certain that the LSA's Miss Ruth M. Keller is the same Ruth Mildred Keller who was a graduate of OSU-OSU's Ruth M. Keller was a woman with a considerable amount of education for the time and a professional interest in language, to judge from her Latin degree and her undergraduate coursework as recorded on her transcript. ${ }^{3}$ She lived for part of her post-OSU life in Cambridge, MA, and died in 1977. She seems not to have married, as no spouse name is given in OSU's Alumni Records, so she would have been a 'Miss' in 1924 at the time of the founding of the LSA. $^{4}$

Moreover, she surely had contact with LSA FMs Bolling and Elden through her coursework. Her transcript reveals that she took Latin classes each year as an undergrad-

\footnotetext{
${ }^{3}$ She entered OSU with advanced standing in French and German, languages she continued to study as an undergraduate, for instance. We obtained the transcript (actually, a list of courses she registered for, with all of her grades for the courses blotted out for reasons of privacy) through an official request made to the Office of the Registrar at OSU; we thank Michael Wright, Associate Registrar at OSU, for granting us access to this information.

${ }^{4}$ Ruth M. Keller is no relation to May Lansfield Keller, a FM about whom much is known (cf. Falk 1994, Turnbull 1975), as May Keller was an only child and had no children herself (Julia Falk, p.c., Dec. 17, 2003).
} 
uate, from 1911 to 1915, including some summer courses, even before she did her M.A. work in Latin; and she also took two years of Greek (1913-1915). Since Elden came to OSU in 1900 and Bolling in 1913, they were teaching Latin and Greek during the period in which Miss Keller undertook her study. It is hard to imagine that she did not cross paths with these professors, though since the record of her classes does not include instructor information we cannot be certain that she actually took classes with either of them. ${ }^{5}$

We therefore suggest that Ruth Mildred Keller became a foundation member of the LSA largely as a result of her personal contacts with two (and possibly more) influential linguists on campus. ${ }^{6}$ We base this hypothesis in large part on what we see as the critical role of personal contacts among FMs.

That is, it is presumably no accident that there were so many FMs from two universities with which Bolling had contact before coming to OSU: Johns Hopkins University in Baltimore, MD, and Catholic University in Washington, DC. Bolling received his Ph.D. from Johns Hopkins in 1896 and went on to teach at Catholic University from 1895-1913; he returned to Johns Hopkins to take up a fellowship in 1913, before leaving for OSU. The continued professional contacts he undoubtedly maintained with former colleagues may well have made some difference here, at the very least in terms of decisions about recipients for the call for the creation of the society.

Furthermore, we can see several networks of personal contacts among the FMs; we survey just some of those at Ohio State, but we are confident that their contacts are representative of the networks involving other FMs.

(1) Leonard Bloomfield was the nephew of Maurice Bloomfield, who was an important linguist at the time from Johns Hopkins, as well as signer of the call for a linguistic society, foundation member of the LSA, and its second president. ${ }^{7}$ Leonard Bloomfield was greatly influenced by his professor at the University of Wisconsin, Eduard Prokosch (who later moved to Bryn Mawr), and by Francis A. Wood at the University of Chicago, both of whom were also FMs. ${ }^{8}$

(2) Wallace S. Elden also studied at Johns Hopkins, and being in Latin no doubt had interactions with Maurice Bloomfield and possibly Bolling too (inasmuch as Bolling was in the Washington area from 1895 through 1914).

(3) Claude Anibal studied under Elijah Clarence Hills at Indiana University; Hills moved to the University of California, Berkeley in 1922 and is also listed as an FM.

\footnotetext{
${ }^{5}$ Unfortunately, details on Smith's tenure at OSU are spotty, so that while we know that he was there in the 1920s, we are not sure if he was in the department when Miss Keller was a student.

${ }^{6}$ Her transcript also reveals that she took two years of psychology (1913-1915), and thus possibly had contact as well with Weiss, who began teaching at OSU in 1912. Contact with Esper would also have been possible, though not through psychology; he was a student of Bolling's at this time. Since Keller was no longer a student at OSU when the LSA was founded in 1924, her listing as an FM suggests that she maintained contact with some members of the OSU contingent.

${ }^{7}$ Indeed, in Leonard Bloomfield's arguments for 'Why a linguistic society?' (Bloomfield 1925) can be seen an echo of Maurice Bloomfield's words in 1919: 'There is pathos in that comparative philologians in America have neither independent association nor special organ of publicity' (as cited in his obituary; Bolling 1928:214). Bolling also studied under Maurice Bloomfield in his years at Johns Hopkins (Hoenigswald 1964: 329).

${ }^{8}$ Prokosch was also a signer of the call and president of the LSA in 1930. In his obituary of Prokosch, Bloomfield describes how he decided that he should 'always work in linguistics' early in his first meeting with Prokosch, going on to say that '[a]t the end of the two years of pupilhood that followed, I knew no greater intellectual pleasure than to listen to Prokosch' (Bloomfield 1938:12).
} 
(4) Olin H. Moore served as Associate Editor of Language from 1932-1935 and thus surely worked closely with editor Bolling.

(5) Erwin A. Esper studied Greek at OSU under Bolling, earning his B.A. in 1917, and served as Bolling's teaching assistant for a year afterwards. He then studied psychology under Weiss, receiving his M.A. in 1920 and his Ph.D. in 1923 from OSU.

(6) Albert P. Weiss had close personal and professional contacts with Bloomfield in particular at OSU (see discussion below) and served as advisor to Esper in his graduate studies.

Looking beyond OSU, the recognition of the importance of personal contacts probably explains other facts about the FMs. In particular, presumably it was the presence of Roland Kent at the University of Pennsylvania that explains why there were so many FMs from that institution (twenty-nine). Kent was also a signer of the call, an FM, and life member after 1927; he was the presiding officer at the first LSA meeting in December 1924, and he served as the Secretary/Treasurer from 1924-1940 and as President in $1941 .^{9}$ It is clear too that Kent was the sort of person who 'knows everyone'; during his years as Secretary/Treasurer he was responsible for much of the 'Notes and Personalia' section that appeared at the end of each issue of Language and contained information about members, including obituaries, and other items of interest to the field in general. ${ }^{10}$ We note also that Kent was a Visiting Professor at OSU during the summer of 1921 (Lane 1953).

Taking the role of personal contacts into consideration also helps to explain some facts about the disciplinary reach of the LSA in the early period. In particular, as a field, psychology was relatively poorly represented among FMs, with only four out of 264. This is understandable since the call for the formation of the LSA went out from language department scholars and was directed at their colleagues and contacts. ${ }^{11}$ Interestingly, of the four, two (thus, 50\%, though $n$ is rather small here) came from OSU.

The two OSU psychologists, Weiss and Esper, were clearly in contact with the linguists on campus, and indeed, Bloomfield's association with Weiss may have contributed to his founding role in the society. ${ }^{12}$ Bloch notes that it was Bloomfield's association with Weiss that led to his becoming a behaviorist by 1933, and he states that

${ }^{9}$ His contributions to the LSA went even deeper; in his obituary of Kent, George Lane notes:

That [the LSA] survived its difficult infancy, that even in the bitter years of the depression it not only held its own but grew in membership and effectiveness, we owe above all to the unceasing efforts of three men: George M. Bolling, the first Editor of LANGuage; Edward Howard Sturtevant, the creator of the Linguistic Institute; and Roland Grubb Kent, the man at the helm. (Lane 1953:1)

${ }^{10}$ Bolling also contributed to this section (Hoenigswald 1964:332), which changed in 1941 to the shorter 'Notes'.

${ }^{11}$ Also so, given the nature of the fields of linguistics and psychology then.

${ }^{12}$ The relationship between Bloomfield and Bolling has already been established, as has that of Esper with both Bolling and Weiss. Esper's 1925 foreword provides a clear picture of the close interactions among these four.

I wish to express my deep sense of obligation to my teachers, George Melville Bolling and Albert P. Weiss. To the former, I owe my interest in language problems; to the latter, my training in pyschological methods as well as guidance and advice throughout this investigation. I am indebted also to Professor Leonard Bloomfield for valuable suggestions in the early stages of this work. (Esper 1925:1)

See also Hockett's introduction to Esper 1973 (which is also an obituary of Esper, who died while the book was in production), in particular the excerpt from a letter written by Esper describing his years at OSU and interactions with Bolling, Weiss, and Bloomfield (Hockett 1973:viii-ix). 
Weiss's work 'had a profound influence on Bloomfield' (Bloch 1949:89, n. 5). In 'Why a linguistic society?', Bloomfield further explains the need for linguists to meet in a place of their own because '[t]he layman-natural scientist, philologian, or man on the street-does not know that there is a science of language ... students of language feel as much need for a professional society as do adherents of any other science' (Bloomfield 1925:1). This emphasis on linguistics as a science, and the role that psychology plays, can also be seen in Bloomfield's obituary of Weiss:

\begin{abstract}
These dates [Weiss's birth and death] will be recorded, it is safe to say, near the beginning of a not unimportant chapter in the history of science: the study of man. Weiss was not a student of language, but he was probably the first man to see its significance. He saw that language supplied the key to those phenomena of human conduct and achievement which hitherto had been attributed to non-physical forces. (Bloomfield 1930:219)
\end{abstract}

It is also significant to note that the second research article to appear in Language was Weiss's 'Linguistics and psychology' $(1.2 .52-57,1925),{ }^{13}$ and the first Language monograph to be published was by Esper (1925). Clearly, the interplay of language and psychology was considered to be important, and perhaps felt to be underserved by the academic community up to that point.

What all of this adds up to is an intriguing picture-fueled in part by the slender OSU documentary record ${ }^{14}$ and in part by enlightened speculation-of the personal dynamics among linguists and language-oriented individuals at Ohio State and within the greater Columbus intellectual community during the formative period of the LSA. ${ }^{15}$ If we can fairly assume that such dynamics were present within other major cities in our field at the time, such as Philadelphia, New York, and Baltimore, then we indeed begin to develop a sense of how scholars around America were working to overcome the isolation Bloomfield referred to. Columbus need not have led the way but was certainly among the leading venues for such activity.

\title{
REFERENCES
}

Bloch, Bernard. 1949. Obituary of Leonard Bloomfield. Language 25.87-98.

BLOOMFIELD, LEONARD. 1925. Why a linguistic society? Language 1.1-5.

BloOMFIeld, LeONARD. 1930. Obituary of Albert Paul Weiss. Language 6.219-21.

BloOMFIELD, LeONARD. 1938. Obituary of Eduard Prokosch. Language 14.310-13.

Bloomfield, Leonard. 1946. Twenty-one years of the Linguistic Society. Language $22.1-3$

Bolling, George Melville. 1928. Obituary of Maurice Bloomfield. Language 4.214-17.

\footnotetext{
${ }^{13}$ The first research article was Edward Sapir's 'Sound patterns in language', in the same issue (1.2.37-51).

${ }^{14}$ The only mention of any of the OSU FMs by name in the official history of the university notes that Bolling helped the war effort (First World War, that is) as a 'Government translator ... [who] spent about 100 hours in reading a set of Lithuanian newspapers published in the United States' (Siebert 1934:162). Seibert notes in general that 'Members of the Romance Languages and German Departments, together with individual members of the Philosophy, English, European History, Greek, and Latin Departments, formed an organization under the chairmanship of Professor M. B. Evans at the request of the post office to read foreign-language newspapers' (ibid.). It is conceivable that some of the OSU FMs besides Bolling were involved as well.

${ }^{15}$ At our presentation of this material at NAAHoLS in January 2004, Mark Amsler of the University of Wisconsin, Milwaukee, told us, based on his own experience at OSU in the 1960s, that the OSU folklorist and English professor Francis Utley had Ms. Keller among his circle of friends and that mention of her is likely to be found in Utley's papers. As yet we have not managed to find a collection of Utley's papers on campus, so corroboration of this intriguing lead remains a task for the future.
} 
ESPER, ERWIn AlLEN. 1925. A technique for the experimental investigation of associative interference in artificial linguistic material. (Language monographs 1.) Philadelphia: Linguistic Society of America.

ESPER, ERWIn AlLEn. 1973. Analogy and association in linguistics and psychology. Athens: University of Georgia Press.

FALK, JULIA S. 1994. The women foundation members of the Linguistic Society of America. Language 70.455-90.

FaLK, Julia S. 2002. On Bloomfield's early role (Letter to Language). Language 78.614. Hockett, Charles F. 1973. Erwin Allen Esper. In Esper 1973, v-xvii.

Hoenigswald, Henry M. 1964. Obituary of George Melville Bolling. Language 40.329-36. Joseph, BRIAN D. 2002. The Editor's Department: Greetings, or, getting to know me. Language 78.1-2.

Lane, George S. 1953. Obituary of Roland Grubb Kent. Language 29.1-13.

Siebert, WiLbur H. 1934. History of The Ohio State University, vol. 4: The university in the Great War, Part 1: Wartime on the campus. Columbus: The Ohio State University Press.

Turnbull, Pauline. 1975. May Lansfield Keller, life and letters 1877-1964. Verona, VA: The McClure Press.

Department of Linguistics

222 Oxley Hall

1712 Neil Ave.

Columbus, OH 43210

[bjoseph@ling.ohio-state.edu]

[hdawson@ling.ohio-state.edu] 